EDITORIAL

\title{
Locomotor de Ruminantes
}

Rüdiger Daniel Ollhoff

Pontifícia Universidade Católica do Paraná (PUCPR), Curitiba, PR, Brasil

Prezados leitores,

No ano de 2018, a Revista Acadêmica: Ciência Animal inovou novamente ao direcionar seus esforços na divulgação de temas específicos, mas que tem despertado o interesse tanto do mundo científico quanto dos profissionais a campo. Assim, foram criadas edições temáticas especiais, que abordaram inicialmente o "Bem-estar e Comportamento Animal" e a "Medicina de Equídeos". Para fecharmos este ano muito produtivo, podemos agora presenteá-los com a edição especial voltada para o "Locomotor de Ruminantes". Nesta edição, os leitores poderão encontrar artigos abordando desde a epidemiologia até o diagnóstico e o tratamento de afecções do sistema locomotor de bovinos, búfalos e ovinos. Como era esperado, pela sua importância na rotina de veterinários podólogos e casqueadores, novamente as lesões do locomotor distal, e em especial aspectos relacionados ao estojo córneo, foram os temas mais descritos.

Um movimento iniciado no "I Simpósio Brasileiro de Claudicação em Ruminantes" de 2016 evento este originado na PUCPR - resultou, em 2017, na primeira publicação normatizando no Brasil as lesões de casco (Borges et al., 2017), e que foi recebida em casa por todos os veterinários do Brasil através da distribuição do Conselho Federal de Medicina Veterinária. Somente um ano após esta primeira investida na padronização da nomenclatura brasileira das afecções do casco, acrescentamos novo marco na história da podologia brasileira: a Revista Acadêmica: Ciência Animal é a primeira revista científica nacional a enfocar, através de uma edição especial, o locomotor ruminante, área de interesse específica da buiatria. Após as primeiras e raras publicações na década de 70 do século passado, aumentando-se o interesse nos anos 90, mas com uma produção de somente 87 artigos brasileiros sobre o locomotor de ruminantes em revistas científicas entre 1974 e 2015, consideramos os onze artigos acrescentados nesta edição um salto.

Esperamos que a expressão de minha euforia os contagie igualmente na leitura das próximas páginas!

* Borges JRJ et al. Doenças dos dígitos dos bovinos: nomenclatura padronizada para o Brasil. Revista CFMV. 2017;23(73):45-52. 